\title{
Jadwal Imunisasi Anak Umur 0 - 18 tahun Rekomendasi Ikatan Dokter Anak Indonesia Tahun 2020
}

Soedjatmiko, Mei Neni Sitaresmi, Sri Rezeki S. Hadinegoro, Cissy B. Kartasasmita, Ismoedijanto, Kusnandi Rusmil, Syawitri P. Siregar, Zakiuddin Munasir, Dwi Prasetyo, Gatot Irawan Sarosa

Satuan Tugas Imunisasi Ikatan Dokter Anak Indonesia

Ikatan Dokter Anak Indonesia secara periodik mengkaji rekomendasi jadwal imunisasi untuk menyesuaikan dengan berbagai perkembangan yang terkait dengan jadwal imunisasi di Indonesia. Jadwal imunisasi 2020 ini bertujuan agar dapat digunakan oleh anggota IDAI dalam memenuhi keinginan masyarakat mendapatkan vaksin yang lebih lengkap. Perubahan pada rekomendasi tahun 2020 adalah pada imunisasi Hepatitis B, IPV, BCG, DTP, Hib, Campak /MR/MMR, JE, Varicella, Hepatitis A dan Dengue. Jadwal imunisasi lain tidak ada perubahan. Untuk memudahkan dalam melaksanakannya dilampirkan juga tabel jadwal imunisasi tahun 2020. Untuk memahami dasar pertimbangan jadwal imunisasi dan perubahannya perlu mempelajari uraian di dalam artikel ini dan keterangan dibawah tabel tersebut untuk diterapkan ke dalam layanan imunisasi. Sari Pediatri 2020;22(4):252-60

Kata kunci: imunisasi, jadwal, vaksin

\section{Immunization Schedule for Children Aged 0 - 18 Years Old Indonesian Pediatrics Society Recommendation 2020}

Soedjatmiko, Mei Neni Sitaresmi, Sri Rezeki S. Hadinegoro, Cissy B. Kartasasmita, Ismoedijanto, Kusnandi Rusmil, Syawitri P. Siregar, Zakiuddin Munasir, Dwi Prasetyo, Gatot Irawan Sarosa

Indonesia Pediatrics Society periodically reviewed the immunization schedule recommendation for adjusting to any finding in vaccine studies, changing of policy or programs involved to the immunization schedule in Indonesia. The objective of the 2017 recommendation is to be used by IPS members in fulfilling public demand for more complete vaccines. The revision of immunization schedule in the 2020 recommendation include in Hepatitis B, IPV, BCG, DTP, Hib, Measles /MR/MMR, JE, Varicella, Hepatitis A and Dengue. A table of the 2020 immunization schedule is available in the end of this paper. It is recommended to read carefully this paper for conceived the reasons of recommendation and the important notes bellow the tabel for the practical implementation in the immunization services. Sari Pediatri 2020;22(4):252-60

Keyword: immunization, schedule, vaccine

Alamat korespondensi: Satgas Imunisasi IDAI. Gedung Ikatan Dokter Anak Indonesia Jalan Salemba 1 no. 5 Jakarta Pusat. Email:satgas.imunisasi@idai.or.id 
S atuan Tugas Imunisasi IDAI secara berkala meninjau ulang jadwal imunisasi untuk anak di Indonesia dengan mempertimbangkan perkembangan berbagai program imunisasi di Indonesia dan rekomendasi WHO. Jadwal imunisasi rekomendasi IDAI tahun 2020 ini mempertimbangkan WHO position paper terbaru untuk berbagai vaksin, Permenkes No. 12 tahun 2017 tentang penyelenggaraan imunisasi, dan kebijakan Kemenkes terkait program imunisasi global, antara lain, eradikasi Polio (Erapo), eliminasi Tetanus Neonatorum (ETN), pengendalian Campak Rubella, pencegahan Pneumonia, pencegahan Kanker Leher Rahim dan pencegahan Japanese Ensefalitis. Revisi ini juga memperhatikan vaksin yang tersedia di Indonesia, keamanan dan imunogenitas vaksin, epidemiologi penyakit yang dapat dicegah dengan imunisasi dan hasil uji klinik vaksin di Indonesia.

\section{Hepatitis B}

Di dalam jadwal imunisasi IDAI tahun 2017 imunisasi Hepatitis B (HB) paling baik diberikan dalam waktu 12 jam setelah lahir, sedangkan di dalam jadwal imunisasi tahun 2020 sebaiknya diberikan segera setelah lahir pada semua bayi sebelum berumur 24 jam.

\section{Dasar pertimbangan}

Perubahan ini sesuai dengan rekomendasi WHO position paper on Hepatitis B Vaccines 2017 bahwa imunisasi HB sebaiknya diberikan pada semua bayi sebelum berumur 24 jam. Bayi-bayi yang tidak mendapat vaksin HB pada waktu lahir berisiko terinfeksi 3.5 kali lebih besar dibandingkan dengan bayi yang mendapat imunisasi waktu lahir. ${ }^{1,2}$ Apabila dosis pertama diberikan 7 hari setelah lahir, bayi yang lahir dari ibu HBsAg (+) risiko infeksi meningkat 8,6 kali dibandingkan dengan pemberian vaksin $\mathrm{HB}$ pada hari 1-3 setelah lahir. ${ }^{1,3}$

Sesuai $W H O$ position paper on Hepatitis $B$ vaccine 2017 di dalam jadwal 2020 ditambahkan keterangan bayi dengan berat lahir kurang dari 2000g, imunisasi HB sebaiknya ditunda sampai berumur 1 bulan atau lebih. Hal ini karena sebagian bayi dengan berat lahir kurang dari $2000 \mathrm{~g}$ tidak dapat memberikan respons imun seperti bayi cukup bulan dan berat lahir normal, tetapi mulai usia kronologis 1 bulan dapat memberikan respons imun adekuat. ${ }^{4}$

Di dalam jadwal imunisasi tahun 2020 imunisasi HB selain diberikan pada umur 2, 3 dan 4 bulan, juga diberikan pada umur 18 bulan bersama DTwP atau DTaP sesuai dengan jadwal imunisasi HB di Permenkes No. 12 tahun 2017.5 Dengan tambahan imunisasi HB pada umur 18 bulan diharapkan menghasilan proteksi lebih tinggi pada usia sekolah dan remaja, karena di beberapa negara anak yang pernah mendapat imunisasi HB lengkap pada masa bayi seroproteksi rendah pada usia sekolah sampai remaja. Di Alaska ${ }^{6}$ pada umur $4-$ 13 tahun seroprotektif $12,5 \%$, di $\operatorname{Iran}^{7}$ pada umur 6 - 18 tahun seroproteksi $44 \%$, di Jakarta ${ }^{8}$ umur 10-12 tahun seroproteksi 38\%.

\section{Inactivated Poliovirus Vaccine (IPV)}

Di dalam jadwal imunisasi 2017 IPV paling sedikit harus diberikan 1 kali bersamaan dengan OPV3. Pada jadwal imunisasi 2020 bOPV atau IPV selanjutnya diberikan bersama DTwP atau DTaP, IPV minimal diberikan 2 kali sebelum berumur 1 tahun.

\section{Dasar pertimbangan}

Perubahan ini memperhatikan hasil studi Fadliana dan kawan-kawan di Bandung pada tahun $2018^{9}$ dengan pemberian 1 kali IPV bersama OPV 4 menghasilkan perlindungan yang lebih rendah terhadap polio serotipe 2, berbeda bermakna dari serotipe 1 dan 3 yang lebih tinggi. Dengan memberikan IPV lebih dari 1x bersama DTwP atau DTaP diharapkan memberikan perlindungan lebih tinggi terhadap polio serotipe 2 . Mengingat cakupan IPV di Indonesia masih sangat rendah, sedangkan bOPV tidak mengandung polio serotipe 2 dan cVDPV2 masih ditemukan di beberapa negara, dianjurkan memberikan IPV minimal 2 kali sebelum berumur 1 tahun.

\section{Bacillus Calmette Guerine (BCG)}

Di dalam jadwal imunisasi tahun 2017; BCG optimal diberikan usia 2 bulan, sedangkan di jadwal imunisasi 2020 sebaiknya diberikan segera setelah lahir atau sesegera mungkin sebelum bayi berumur 1 bulan. 


\section{Dasar pertimbangan}

Perubahan ini berdasarkan rekomendasi WHO position paper BCG vaccine 2018 untuk negara dengan kejadian tuberkulosis tinggi BCG diberikan pada bayi segera setelah lahir. ${ }^{10}$ Imunisasi BCG pada neonatus memberikan perlindungan $82 \%$ terhadap tuberkulosis paru (RR 0,18, IK 95\%: 0,15-0,21) ${ }^{11}$ dan menurunkan tuberkulosis berat sebanyak $90 \% .{ }^{12}$ Bila imunisasi BCG tidak dapat diberikan pada waktu lahir sebaiknya diberikan segera tidak ditunda sebelum terpapar infeksi. ${ }^{10}$

\section{Difteri, Tetanus, Pertusis (DTP)}

Di dalam jadwal imunisasi 2017 booster DTP diberikan pada umur 5 tahun, sedangkan di jadwal imunisasi 2020 pada umur 5 - 7 tahun, atau pada program BIAS kelas 1 sesuai dengan Permenkes No. 12 tahun 2017.

\section{Dasar pertimbangan}

Perubahan ini mempertimbangkan WHO position paper on diphteria vaccine $(2017)^{13}$ dan tetanus vaccine $(2017)^{14}$ yang merekomendasikan booster imunisasi difteri dan tetanus toksoid pada umur 4-7 tahun. Jadwal imunisasi 2020 juga mempertimbangkan WHO position paper on pertusis (2015) ${ }^{15}$ yang menyatakan bahwa perlindungan terhadap pertusis dengan vaksin aseluler akan menurun sebelum berumur 6 tahun maka diperlukan booster sebelum berumur 6 tahun, maka booster DTP diberikan pada umur 5- 7 tahun. Booster pada umur 18 bulan dan $10-18$ tahun tidak berubah.

\section{Haemophilus Influenzae B (Hib)}

Di dalam jadwal imunisasi tahun 2017 booster Hib diberikan pada umur 15 - 18 bulan, sedangkan di dalam jadwal 2020 diberikan pada umur 18 bulan bersama DTwP atau DTaP.

\section{Dasar pertimbangan}

Jadwal ini sesuai dengan $W H O$ position paper mengenai Hib tahun 2013 bahwa setelah imunisasi dasar Hib diberikan booster 1 kali sekurangnya-kurangnya 6 bulan setelah imunisasi dasar. ${ }^{16} \mathrm{Jadwal}$ ini sesuai pula dengan Permenkes No. 12 tahun 2017 booster Hib diberikan pada usia 18 bulan di dalam vaksin pentavalen. ${ }^{5}$

\section{Pneumokokus}

Di dalam jadwal imunisasi 2017: vaksin PCV apabila diberikan pada usia 7-12 bulan, PCV diberikan 2 kali dengan interval 2 bulan; dan pada usia lebih dari 1 tahun diberikan 1 kali. Keduanya perlu booster pada usia lebih dari 12 bulan atau minimal 2 bulan setelah dosis terakhir. Pada anak usia di atas 2 tahun PCV diberikan cukup satu kali.

Di dalam jadwal imunisasi 2020 jika belum pernah diberikan pada umur 7 - 12 bulan, berikan PCV 2 kali dengan jarak minimal 1 bulan dan booster setelah umur 12 bulan dengan jarak sedikitnya 2 bulan dari dosis sebelumnya. Jika belum pernah diberikan pada umur 1- 2 tahun berikan PCV 2 kali dengan jarak 2 bulan. Jika belum pernah diberikan pada umur 2 - 5 tahun PCV10 diberikan 2 kali dengan jarak minimal 2 bulan, PCV13 diberikan 1 kali. Pada Program Demonstrasi Imunisasi Pneumokokus Konjugasi Kementerian Kesehatan PCV diberikan pada umur 2 bulan, 3 bulan, dan 12 bulan.

\section{Dasar pertimbangan}

Perubahan tersebut di atas berdasarkan WHO position paper pneumokokus (2019) $)^{17}$ dan Keputusan Menteri Kesehatan Republik Indonesia No. HK.01.07/ Menkes/199/2017 Pelaksanaan Demonstrasi Pemberian Imunisasi Pneumokokus Konyugasi di Kabupaten Lombok Barat dan Kabupaten Lombok Timur. ${ }^{18}$ Program Kemenkes tersebut memberikan PCV pada umur 2 bulan, 3 bulan dan 12 bulan sesuai dengan WHO position paper mengenai pneumokokus (2019) yang melaporkan meta analisis dan kajian sistematik 5 uji klinik dengan randomisasi bahwa pemberian PCV dengan dosis primer 2 atau 3 kali menghasilkan tingkat seropositif tinggi (konsentrasi antibodi $>0,35 \mathrm{~g} / \mathrm{ml}$ ) pada sebagian besar serotipe. ${ }^{17}$

Dengan dosis $3 p+1$ tingkat seropositive lebih tinggi untuk serotipe $6 \mathrm{~B}$ dan $23 \mathrm{~F} .{ }^{19} \mathrm{Uji}$ klinik dengan randomisasi pada 400 bayi cukup bulan di Belanda 2010-2011 yang memberikan PCV13 dengan jadwal 
berbeda, yaitu 2-4-6 bulan, 3-5 bulan, 2-3-4 bulan atau 2-4 bulan, kemudian diberikan booster pada umur 11,5 bulan, titer antibodi 1 bulan setelah booster tidak berbeda bermakna secara statistik pada keempat jadwal tersebut. Namun jadwal 2-4-6 bulan ditambah 1 booster $(3 p+1)$ cenderung menghasilkan respons imun lebih baik untuk serotipe 18C, $23 \mathrm{~F}, 6 \mathrm{~B}, 3$, 9, dan $1 .{ }^{20}$ Serotipe tersebut banyak ditemukan di Indonesia.

\section{Rotavirus}

Di dalam jadwal imunisasi 2020 vaksin rotavirus monovalen (RV1) diberikan 2 dosis, dosis pertama diberikan mulai usia 6-12 minggu, dosis kedua diberikan dengan interval minimal 4 minggu dan dosis kedua diberikan paling lambat 24 minggu. Vaksin rotavirus pentavalen (RV5) diberikan dalam 3 dosis. Dosis pertama diberikan pada umur 6-12 minggu. Dosis kedua dan ketiga diberikan dengan interval 4 -10 minggu. Dosis ketiga paling lambat diberikan pada umur 32 minggu.

\section{Dasar pertimbangan}

Kajian sistematik dan meta analisis untuk menilai hubungan antara vaksin rotavirus dengan risiko kejadian intususepsi di neonatus dan bayi oleh $\mathrm{Lu}^{21}$ (2019) di 33 negara dari 4 benua dengan melibatkan 25 uji klinis dengan 200.594 subjek (104.647 menerima RV dan 95.947 plasebo) menyimpulkan tidak ada hubungan antara intususepsi dengan pemberian vaksin rotavirus. Risiko relatif intususepsi 1 bulan setelah pemberian vaksin sebesar 1,14 (95\% IK 0,49-2,64), sesudah 1 tahun sebesar 0,84 (95\% IK 0,53-1,32), dan dalam 2 tahun setelah vaksinasi sebesar 0,91 (95\% IK 0,55-1,52). Meskipun demikian, kajian sistematik dan meta analisis yang dilakukan oleh Koch $\mathrm{dkk}^{22}$ mendapatkan hasil risiko relatif terjadinya intususepsi lebih besar bila rotavirus dosis pertama diberikan setelah usia 3 bulan; RR terjadinya intususepsi sebesar 1,7 (95\% IK 1,1-2,7) bila dosis pertama diberikan $<3$ bulan dan 5,6 (95\% IK 4,3-7,2) bila diberikan $>3$ bulan. Beberapa penelitian tentang insiden intususepsi sebelum dan sesudah pemberian vaksin rotavirus menunjukkan prevalensi intususepsi meningkat dengan bertambahnya usia. Penelitian di UK, menunjukan setelah implementasi vaksin rotavirus dalam program nasional dengan jadwal pemberian 8 dan 12 minggu, annual hospital admission kasus intususepsi pada usia 8-12 minggu sebesar 46/100.000 meningkat menjadi 70/100.000 pd usia 13-16 minggu dan 152/100.000 pada usia 17-24 minggu. ${ }^{23}$ Sementara penelitian di Korea mendapatkan insiden intususepsi setelah period vaksinasi (2009-2015) sebesar 42/100.000 pada usia 6-14 minggu, 157/100.00 pada usia 15-24 minggu dan 243/100.00 pada usia $25-34$ minggu. ${ }^{24}$ Oleh karena itu, sebaiknya pemberian vaksin rotavirus diberikan sebelum 12-14 minggu untuk mengurangi risiko terjadinya intususepsi.

Vaksin rotavirus monovalen (RV1) diberikan secara oral dalam 2 dosis. Dosis pertama pada umur $>6$ minggu, dosis kedua diberikan dengan interval minimal 4 minggu dan diselesaikan paling lambat 24 minggu. ${ }^{25}$ Vaksin rotavirus pentavalen (RV5) diberikan secara oral dalam 3 dosis, dosis pertama pada umur 6-12 minggu, interval antar dosis 4-10 minggu, dan dosis ketiga diselesaikan maksimal pada umur 32 minggu. ${ }^{26}$

\section{Influenza}

Di dalam jadwal imunisasi tahun 2017 imunisasi influenza diberikan pada usia lebih dari 6 bulan, sedangkan di dalam jadwal tahun 2020 diberikan mulai umur 6 bulan.

\section{Dasar pertimbangan}

Jadwal ini sesuai dengan WHO position paper vaccine against influenza $(2012)^{25}$ bahwa imunisasi influenza diberikan mulai umur 6 bulan karena tingginya kejadian influenza berat pada umur 6-23 bulan kemudian 2-5 tahun.

\section{Campak dan Rubella}

Di dalam jadwal imunisasi tahun 2017 pada umur 9 bulan diberikan imunisasi campak, sedangkan di dalam jadwal 2020 diberikan campak rubella (MR).

\section{Dasar pertimbangan}

Perubahan ini sesuai dengan WHO position paper 
Rubella vaccine $(2011)^{26}$ dan Keputusan Menteri Kesehatan No. HK 01.07/Menkes/45/2017 tanggal 31 Januari 2017, tentang introduksi imunisasi campak rubella di Indonesia pada umur 9 bulan. ${ }^{27}$ Bila sampai umur 12 bulan belum mendapat vaksin MR, dapat diberikan MMR.

Karena dapat terjadi kegagalan imunisasi primer campak pada $10 \%-15 \%$ anak, ${ }^{28}$ maka harus diberikan vaksin campak ke 2 (bersama rubella) pada umur 1518 bulan. ${ }^{28}$, Selanjutnya, imunisasi MR (atau MMR) diberikan pada umur $5-7$ tahun $^{28}$ atau pada kelas 1 SD dalam program BIAS ${ }^{27}$

Jadwal ini juga sesuai dengan WHO position paper mengenai vaksin mumps $2007^{29}$ yang menganjurkan pemberian vaksin mumps 2 dosis (bersama campak dan rubella) mulai umur $12-18$ bulan. Dosis kedua diberikan pada usia masuk sekolah (school entry) sekitar umur 6 tahun. untuk memberikan perlindungan jangka panjang ${ }^{29}$

\section{Japanese Ensefalitis (JE)}

Di dalam jadwal imunisasi tahun 2017 imunisasi JE diberikan mulai umur 12 bulan, sedangkan di dalam jadwal 2020 mulai umur 9 bulan.

\section{Dasar pertimbangan}

Perubahan ini sesuai dengan Keputusan Menteri Kesehatan RI No. 01.07/Menkes/117/2017 tentang pelaksanaan kampanye dan introduksi imunisasi JE di Bali $^{30}$ dan WHO position paper mengenai JE (2015) bahwa imunisasi JE diberikan mulai umur 9 bulan. ${ }^{31}$

Imunisasi JE direkomendasikan untuk di daerah endemis atau yang akan bepergian ke daerah endemis. Surveilans JE di Indonesia tahun 2016 ada 9 provinsi melaporkan kasus JE: Bali, Kalimantan Barat, Sulawesi Utara, Nusa Tenggara Timur, DKI Jakarta, DI Yogyakarta, Jawa Tengah, Nusa Tenggara Barat, dan Kepulauan Riau, dengan kasus JE terbanyak di provinsi Bali. ${ }^{32}$

\section{Varisela}

Di dalam jadwal imunisasi tahun 2017 imunisasi varisela diberikan setelah usia 12 bulan, terbaik pada usia sebelum masuk sekolah dasar. Apabila diberikan pada usia lebih dari 13 tahun perlu 2 dosis dengan interval minimum 4 minggu.

Di dalam jadwal imunisasi tahun 2020 imunisai varisela diberikan mulai umur 12 - 18 bulan. Pada umur $1-12$ tahun diberikan 2 dosis dengan interval 6 minggu sampai 3 bulan. Pada umur 13 tahun atau lebih diberikan 2 dosis dengan interval 4 sampai 6 minggu.

\section{Dasar pertimbangan}

Perubahan ini sesuai dengan rekomendasi WHO position paper tentang varisela (2014) untuk menurunkan kasus varisela dan mencegah terjadinya kejadian luar biasa. ${ }^{33}$ Meta analisis tentang efikasi vaksin varisela menyimpulkan dosis tunggal cukup efektif dalam mencegah varisela dengan efikasi $81 \%$, sedangkan 2 dosis meningkatkan efikasi menjadi $92 \% .{ }^{34}$ Beberapa penelitian lain juga menganjurkan pemberian 2 dosis. ${ }^{35}$

\section{Hepatitis A}

Di dalam keterangan jadwal imunisasi tahun 2017 imunisasi Hepatitis A diberikan mulai umur 2 tahun, $2 x$ dengan interval $6-12$ bulan, sedangkan di dalam jadwal 2020 diberikan mulai umur 1 tahun, dosis ke-2 diberikan setelah 6 bulan sampai 18 bulan kemudian.

\section{Dasar pertimbangan}

Jadwal ini sesuai dengan WHO position paper tentang hepatitis A (2012) $)^{36}$ dan beberapa penelitian lain. ${ }^{37}$

\section{Dengue}

Di dalam keterangan jadwal imunisasi 2017 tertulis imunisasi dengue diberikan pada usia 9-16 tahun dengan jadwal 0,6,12 bulan. Di dalam jadwal 2020 ditambahkan prasyarat : diberikan pada anak umur $9-16$ tahun yang pernah dirawat dengan diagnosis dengue dan dikonfirmasi dengan deteksi antigen (rapid dengue test NS-1 atau PCR ELISA), atau IgM anti dengue. Bila tidak ada konfirmasi tersebut 
dilakukan pemeriksaan serologi IgG anti dengue untuk membuktikan apakah pernah terinfeksi dengue.

\section{Dasar pertimbangan}

Hal ini sesuai dengan WHO position paper dengue vaccine $(2018)^{38}$ berdasarkan penelitian di beberapa negara termasuk Indonesia bahwa efikasi vaksin dengue lebih tinggi bila imunisasi dilakukan pada umur 9 16 tahun $(65,6 \%)$ dibandingkan umur $2-8$ tahun $(44,6 \%) .{ }^{39}$ Di Indonesia, efikasi imunisasi dengue pada umur 9 tahun atau lebih dapat mencegah menderita dengue berat $93,2 \%, 39$

WHO position paper dengue vaccine 2018 menganjurkan dilakukan skrining pra vaksinasi karena imunisasi dengue pada anak umur 9-16 tahun dengan seronegatif rasio hazard (HR) kemungkinan dirawat di rumah sakit akibat infeksi dengue lebih besar, yaitu 1,41 dan kemungkinan menderita dengue berat lebih besar, yaitu sebesar 2,44..$^{38,40}$ Sebaliknya, imunisasi dengue pada anak seropositif rasio hazard (HR) untuk dirawat di rumah sakit akibat infeksi dengue lebih kecil, yaitu 0,21 dan kemungkinan menderita dengue berat juga lebih kecil, yaitu $0,16 .^{38,40}$

\section{Human Papiloma Virus (HPV)}

Di dalam jadwal imunisai tahun 2017 imunisasi HPV diberikan mulai usia 10 tahun. Di dalam jadwal 2020 diberikan pada anak perempuan umur 9-14 tahun 2 kali dengan jarak $6-15$ bulan (atau pada program BIAS kelas 5 dan 6). Umur 15 tahun atau lebih diberikan 3 kali dengan jadwal 0, 1, 6 bulan (vaksin bivalen) atau 0, 2, 6 bulan (vaksin quadrivalen).

\section{Dasar pertimbangan}

Jadwal ini sesuai dengan Keputusan Menteri Kesehatan RI No. 01.07/Menkes/194/2017 tentang Pelaksanaan Demonstrasi Pemberian Imunisasi HPV di Surabaya, Manado, dan Makasar, ${ }^{41}$ serta WHO position paper mengenai HPV (2017). ${ }^{42}$ Imunogenisitas vaksin HPV dengan 2 dosis ( 0,6 bulan atau 0,12 bulan) pada perempuan umur $9-14$ tahun setara dengan 3 dosis (0, 1-2, 6 bulan) pada perempuan berumur $15-24$ dan 26 tahun. ${ }^{43,44}$

\section{Penutup}

Untuk imunisasi dasar yang harus diberikan beberapa kali (imunisasi serial) maka interval tidak boleh lebih cepat 5 hari atau lebih dari interval minimum, atau umurnya lebih muda dari umur minimal yang direkomendasikan karena akan menghasilkan respons imun sub optimal. Bila hal itu terjadi maka imunisasi perlu diulang dengan interval atau pada umur minimal yang direkomendasikan. ${ }^{45}$ Toleransi masa tenggang (grace periode) maksimal 4 hari dari interval yang dianjurkan, atau maksimal 4 hari dari umur minimal yang direkomendasikan. Kalau interval imunisasi lebih lama dari yang direkomendasikan berisiko terjadi infeksi sebelum diberikan dosis lengkap sesuai rekomendasi. ${ }^{45}$ Namun, imunisasi terlambat tidak perlu pengulangan atau penambahan dosis karena tidak akan mengurangi konsentrasi antibodi final setelah diberikan dosis lengkap sesuai rekomendasi. ${ }^{45}$

\section{Daftar pustaka}

1. World Health Organization. Hepatitis B vaccines: WHO position paper-July 2017. Wkly Epidemiol Rec 2017;27:38990.

2. Lee C, Gong Y, Broke J, Boxall EH, Gluud C. Hepatitis B immunization for newborn infants of hepatitis B surface antigen-positive mothers. Cochrane Database of Systematic Reviews 2006;(2):CD004790.

3. World Health Organization. Summary of findings per outcome of timing of the first dose of recombinant DNA HBV vaccines. SAGE Meeting - October 2017. Diunduh 4 Mei 2020. Didapat dari: http://www.who.int/immunization/ sage/meetings/2016/october/SAGE_yellow_book_october_2016. pdf?ua $=1$.

4. American Academy of Pediatrics. American Academy of Pediatrics Committee on Infectious Diseases. HBV vaccination among low birth weight children (LBW). Diunduh $4 \mathrm{Mei}$ 2020. Didapat dari: http://www.who.int/immunization/sage/ meetings/2016/october/4_Systematic_review_of_safety_efficacy_ hep_b.pdf?ua $=1$

5. Kementerian Kesehatan RI. Penyelenggaraan Imunisasi. Peraturan Menteri Kesehatan RI nomor 12 tahun 2017. Jakarta: Kemenkes RI; 2017.

6. Petersen KM, Bulkow LR, McMahon B, Zanis C, Getty M, Peters H, Parkinson AJ. Duration of Hepatitis B Immunity in Low Risk Children Receiving Hepatitis B Vaccinations from Birth. Pediatr Infect Dis J 2004;23:650-5.

7. Azarkar Z, Ebrahimzadeh A, Sharifzadeh G, dkk. Persistence of immunity to hepatitis $B$ vaccine as in fants, 17 years earlier. Caspian J Intern Med 2018;9:184-8. 
8. Suraiyah, Oswari H, Poesponegoro HD. Proporsi seroproteksi Hepatitis B pada usia 10-12 tahun dengan riwayat imunisasi dasar Hepatitis B lengkap pada dua sekolah dasar di Jakarta. Sari Pediatri 2008;9:423-8.

9. Fadlyana E, Dhamayanti M, Tarigan R, Mulia Sari R, Bachtiar NS, Kartasasmita CB, Rusmil K. Immunogenicity and safety profile of a primary dose of bivalent oral polio vaccine given simultaneously with DTwP-Hb-Hib and inactivated poliovirus vaccine at the 4 th visit in Indonesian infants. Vaccine 2020;38:1962-7.

10. World Health Organization. BCG vaccines: WHO position paper - February 2018. Wkly Epidemiol Rec 2018;8:73-96.

11. Abubakar I, Pimpin L, Ariti C, Beynon R, Mangtani P, Sterne JA. Systematic review and metaanalysis of the current evidence on the duration of protection by bacillus Calmette-Guérin vaccination against tuberculo $\neg$ sis. Health Technol Assess 2013;17:1-372.

12. Mangtani P, Abubakar I, Ariti C, Beynon R, Pimpin L, Fine PE. Protection by BCG vaccine against tuberculosis: A systematic review of randomized controlled trials. Clin Infect Dis 2014;58:470-80.

13. World Health Organization. Diphtheria vaccine: WHO position paper - August 2017. Wkly Epidemiol Rec 2017;31:425-34.

14. World Health Organization. Tetanus vaccines: WHO position paper - February 2017. Wkly Epidemiol Rec 2017;6:53-76.

15. World Health Organization. Pertussis vaccines: WHO position paper - August 2015. Wkly Epidemiol Rec 2015;35:433-60.

16. World Health Organization. Haemophilus influenzae type $b$ (Hib) Vaccination. WHO position paper September 2013. Wkly Epidemiol Rec 2013;39:413-28.

17. World Health Organization. Pneumococcal conjugate vaccines in infants and children under 5 years of age: WHO position paper - February 2019. Wkly Epidemiol Rec 2019;8:85-104.

18. Kementerian Kesehatan RI. Pelaksanaan demonstrasi pemberian imunisasi pneumokokus konyugasi di Kabupaten Lombok Barat dan Kabupaten Lombok Timur. Keputusan Menteri Kesehatan Republik Indonesia no. HK.01.07/ Menkes/199/2017. Jakarta: Kemenkes RI; 2017.

19. Scotta P, Rutjesa AWS, Bermetza L, dkk. Comparing pneumococcal conjugate vaccine schedules based on 3 and 2 primary doses: Systematic review and meta-analysis. Vaccine 2011:9711-21

20. Spijkerman J, Veenhoven RH, Alienke J, dkk. Immunogenicity of 13-valent Pneumococcal conjugate vaccine administered according to 4 different primary immunization schedules in infants: a randomized clinical trial. JAMA 2013;310:930-7.

21. Lu HL, Ding Y, Goyal H, Xu HG. Association between rotavirus vaccination and risk of intussusception among neonates and infants: a systematic review and meta-analysis. JAMA Netw open. 2019;2:e1912458.

22. Koch J, Harder T, von Kries R, Wichmann O. The risk of intussusception after rotavirus vaccination-a systematic literature review and meta-analysis. Dtsch Arztebl Int 2017; 114:255-62.

23. McGeoch LJ, Finn A, Marlow RD. Impact of rotavirus vaccination on intussusception hospital admissions in England,
Vaccine 2020;38:5618-26.

24. Cho H-K, Hwang SH, Nam HN, dkk. Incidence of intussusception before and after the introduction of rotavirus vaccine in Korea. PLoS ONE 2020;15:e0238185.

25. GlaxoSmithKline. Biologicals G, Drug IN. WHO package insert Rotarix. Biologicals 2006;1-136.

26. Merck Sharp \& Dohme. RotaTeq. Guidelines for Rotavirus Vaccines. 2008

27. World Health Organization. Vaccines against influenza: WHO position paper-November 2012. Wkly Epidemiol Rec 2012;47:461-76.

28. World Health Organization. Rubella vaccines: WHO position paper-2011. Wkly Epidemiol Rec 2011;29:301-16.

29. Menteri Kesehatan RI. Pelaksanaan kampanye dan introduksi imunisasi Measles dan Rubella di Indonesia. Keputusan Menteri Keseahatan no HK 01.07/Menkes/45/2017; 31 Januari 2017. Jakarta: Kemkes RI; 2017.

30. World Health Organization. Measles vaccines: WHO position paper - April 2017. Wkly Epidemiol Rec 2017;17:205-28.

31. World Health Organization. Mumps virus vaccines. Wkly Epidemiol Rec 2007;7:49-60.

32. Menteri Kesehatan RI. Pelaksanaan kampanye dan introduksi imunisasi JE. Keputusan Menteri Kesehatan RI no 01.07/ Menkes /117/2017; 8 Maret 2017. Jakarta: Kemkes RI; 2017.

33. World Health Organization. WHO position paper : Japanese Encephalitis. Wkly Epidemiol Rec 2015;9:69-88.

34. Garjito TA, Widiarti, Anggraeni YM, Aditama TY. Japanese Encephalitis in Indonesia: an update on epidemiology and transmission ecology. Acta Tropica 2018;187. doi:10.1016/j. actatropica.2018.08.017.

35. 35. World Health Organization. Varicella and herpes zoster vaccines: WHO position paper, June 2014. Wkly Epidemiol Rec. 2014;89(25):265-87.

36. Marin M, Marti M, Kambhampati A, Jeram SM, Seward JF. Global varicella vaccine effectiveness: a meta-analysis review article pediatrics. Diakses pada 28 November 2020. Didapat dari: www.aappublications.org/news.

37. Zhu S, Zeng F, Xia L, He H, Zhang J. Incidence rate of breakthrough varicella observed in healthy children after 1 or 2 doses of varicella vaccine: Results from a meta-analysis. Am J Infect Control 2018;46:e1-7.

38. World Health Organization. Position paper: Hepatitis A. Wkly Epidemiol Rec. 2012;87:261-76.

39. Jefferies M, Rauff B, Rashid H, Lam T, Rafiq S. Update on global epidemiology of viral hepatitis and preventive strategies. World J Clin Cases 2018;6:589-99.

40. World Health Organization. Dengue vaccine: WHO position paper - September 2018. Wkly Epidemiol Rec 2018;36:457-76.

41. Hadinegoro SR, Arredondo-García JL, Capeding MR, dkk. Efficacy and long-term safety of a dengue vaccine in regions of endemic disease. N Engl J Med. 2015;373:1195-206.

42. Sridhar S, Luedtke A, Langevin E, dkk. Impact of dengue serostatus on dengue vaccine safety and efficacy. N Engl J Med 2018;379:327-40.

43. Menteri Kesehatan RI. Pelaksanaan demonstrasi pemberian imunisasi HPV di Surabaya, Manado dan Makasar. Keputusan 
Menteri Kesehatan no HK 01.07/Menkes/194/2017; 11 April 2017. Jakarta: Kemenkes RI; 2017.

44. World Health Organization. Human papillomavirus vaccines: WHO position paper - May 2017. Wkly Epidemiol Rec 2017; 19:241-68.

45. Romanowski B, Schwarz TF, Ferguson L, Peters K, Dionne M, Behre U. Sustained immunogenicity of the HPV-16/18 AS04-adjuvanted vaccine administered as a two-dose schedule in adolescent girls: Five-year clinical data and modeling predictions from a randomized study. Hum Vaccin
Immunother 2016;12:20-9.

46. Puthanakit T, Huang LM, Chiu CH, Tang RB, Schwarz TF, Esposito S. Randomized open trial comparing 2-dose regimens of the Human Papillomavirus 16/18 AS04-Adjuvanted vaccine in girls aged 9-14 years versus a 3-dose regimen in women aged 15-25 years. J Infect Dis 2016;21:525-36.

47. Advisory Committee on Immunization Practices. Timing and spacing of immunobiologics. General best practice guidelines for immunization. Diunduh 4 Mei 2020. Didapat dari: https:// www.cdc.gov/vaccines/hcplacip-recs/general-recs/timing.html. 


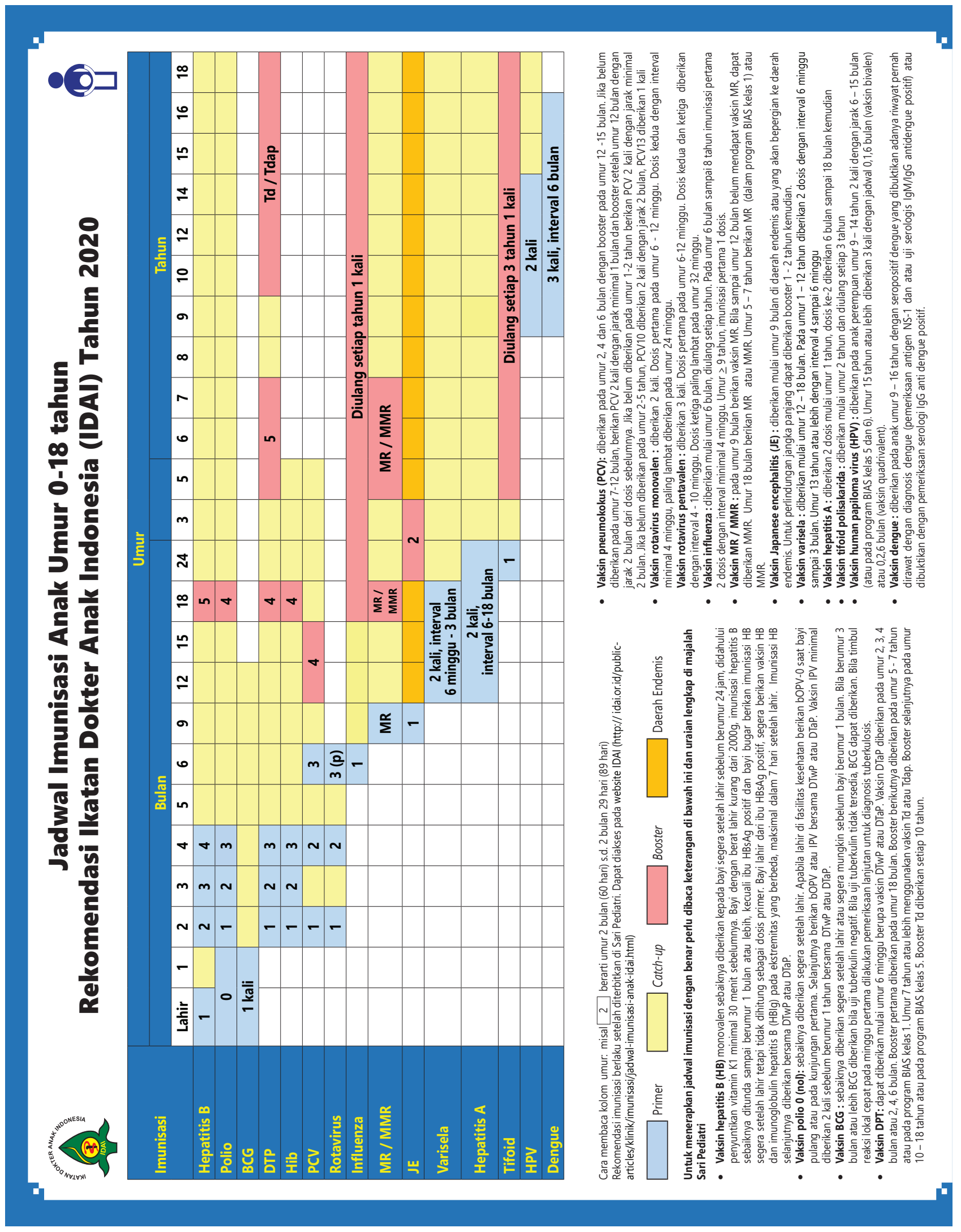

